\title{
CAPITALIZING ON NATIONAL SELF- INTEREST: THE MANAGEMENT OF INTERNATIONAL TELECOMMUNICATION CONFLICT BY THE INTERNATIONAL TELECOMMUNICATION UNION
}

\author{
Donna C. GregG*
}

\section{INTRODUCTION}

In the early days of telecommunication, ${ }^{1}$ technically advanced nations quickly recognized the usefulness of the telegraph in international commerce. There was, however, a considerable obstacle to the development of the new technology's commercial potential. As one observer of this era of telecommunication history points out, "humanity could not fully benefit from all the miraculous possibilities of the electrical telegraph, that tiny instrument which human genius had just invented, unless it could move beyond the narrow, rigid concept of national sovereignty as something absolute, sacrosanct and inviolate."' The success of international telegraphy depended upon the cooperation of nations in permitting the orderly flow of telegraphic messages across national borders and in standardizing equipment and rates.

The need for international cooperation became even more important when wireless communication came into use. Because electromagnetic waves embodying radio messages travel through the air rather than through wires or cables, radio transmissions are not restricted by the territorial considerations that first prompted international coordination of wire communications. Nevertheless, radio could not be used successfully for such important purposes as maritime safety and international commerce without international cooperation and standardization.

Furthermore, even a nation's domestic radio communications can have international ramifications. The physical properties of radio make it difficult to confine transmissions within political boundaries. If the right technical and atmospheric conditions exist, radio waves originating in one country can be received, not just in

Copyright $(1982$ by Law and Contemporary Problems

* Partner, Dow, Lohnes \& Albertson, Washington, D.C.

1. Hereinafter, "telecommunication" will refer to all forms of long long-distance, electronic communication both by wire or cable (e.g., telegraph and, telephone) and by radio (e.g., AM and FM radio broadcasting, shortwaive radio, aeronautical radio and television).

2. Mili, Intemational Jurisdiction in Telecommunication Affairs, 40 TELECOM. J. 122, 123 (1973). 
neighboring jurisdictions, but also in places that are quite remote from the transmitter. ${ }^{3}$ Harmful interference can be averted or minimized only through careful coordination of the power, direction and timing of transmissions on the same or adjacent frequencies. It is well recognized that unless users of radio everywhere participate in the orderly use of the spectrum, the value of radio as a means of national as well as international communication would be greatly diminished and, in some circumstances, totally destroyed. ${ }^{4}$

In his examination of international organization, Goodspeed attributes cooperative efforts in technical fields such as telecommunication to their physical characteristic of "transcending purely national frontiers." International cooperation is even more important to telecommunication today because of conflicts that may be produced by the tremendous rate of technical progress in the field.

This article will examine the potential for conflict and the need for international cooperation in the contemporary telecommunication industry, with a particular focus on the role of the International Telecommunication Union (ITU) in international conflict management. After addressing particular aspects of modern telecommunication which invite international conflict, the article will present an overview of the ITU as the principal instrumentality for maintaining world order in telecommunication. The Union's importance in conflict prevention, dispute resolution, and arbitration will be analyzed in detail. Finally, this article will assess the success of the ITU in conflict management and evaluate the need for change in the ITU as it enters a new era of international telecommunication.

\section{Contemporary Telecommunication Conflicts}

Technology has advanced to the point at which integration of all telecommunication systems into a vast, worldwide network consisting of wire, radio and satellite components is a real possibility. ${ }^{6}$ International standardization and coordinated interconnection of national wire communication systems will be critical to the realization of this potential. The failure or inability of any nation to conform to complex international standards will deprive it of important benefits and may impede other nations from taking full advantage of the new technology as well.

3. An AM radio station, for example, transmits radio waves along the curvature of the earth (ground waves), along line-of-sight paths (direct waves), and straight up (sky-waves). Sky-waves, which are reflected back to earth by particles in various layers of the ionosphere, are responsible for the reception and interference of AM radio at often unpredictable locations at extreme distances from the transmitter, particularly after sunset. For a discussion of the physical properties of radio transmission, see R. HiLLIARD, RADIO BROADCASTING 52-104 (2d ed. 1974).

4. See, e.g., S. Chen, The Theory and Practice of International Organization 147 (rev. ed. 1979).

5. S. Goodspeed, The Nature and Function or International Organization 4 (2d ed. 1967).

6. The possibility of instantaneous, worldwide information transfer no longer exists just in the realm of science fiction. The development of space communication, for instance, enables us to witness live events taking place on other continents or even on other planets. Telecommunication combining wire, space and radio technology will permit the international transfer of funds and data among branches of multinational banks and corporations. For a discussion of the practical international applications of modern telecommunication technology, see J. Martin, Future Developments in TElecommuniCations 339-45 (2d ed. 1977); McGuire, The Information Age: An Introduction to Transborder Data Flow, 20 JURIMETRICS J. 1 (1979). 
Recent technological breakthroughs have also made available a variety of reasonably priced equipment that has in turn created an unprecedented demand for radio frequencies. ${ }^{7}$ Because the commercial applications of radio are quite lucrative, ${ }^{8}$ existing users of radio in industrialized nations are consuming more spectrum space. ${ }^{9}$ At the same time, demand for frequencies from the developing nations has contributed to the crowding of the spectrum because remote or isolated areas and people can be linked together more quickly and economically with radio communication than with transportation systems or wire communication systems. Like competitors for other limited world resources, potential users of radio are bound to come into conflict.

Technology is also producing new modes of telecommunication with their own potential for international conflict. The communications satellite is one such new device with major international ramifications. ${ }^{10}$ Because communications from space satellites can generally be directed to larger geographic areas of the earth with greater reliability than can conventional radio transmissions, the need for international cooperation and the potential for conflict in the satellite field is accentuated. As the use of satellite technology increases, international policy conflicts over occupancy of the geostationary orbit ${ }^{11}$ may be manifested in head-tohead conflicts among nations competing for a finite number of orbital slots in

7. Although the continuing advances in telecommunication technology are expected to increase the efficiency with which we use the spectrum (thereby enabling more users to occupy less space), at present, demand for radio frequencies is meeting or even surpassing available capacity. See J. MARTIN, supra note 6, at 435-36. In recent testimony before the House Subcommittee on International Operations, the Chairman of the FCC discussed the crowding of the AM radio spectrum and recent problems of Cuban radio stations' interference with $\mathrm{AM}$ radio broadcasting in the United States. Statement by Mark $S$. Fowler, Chairman of FCC, House Subcommittee on International Operations (June 4, 1981) (unpublished).

8. According to the most recent Annual Report of the FCC, the United States commercial television and radio broadcast industry reported combined revenues of $\$ 10.7$ billion in calendar 1979 . See 46 FCC ANN. REP. 30 (1980).

9. The increase in frequency usage is reflected in the growth of television broadcasting in selected industrialized nations during the last decade. 1980 data reflect both operating full-service (F) and relay/repeater $(\mathbf{R})$ transmitters.

\begin{tabular}{l} 
COUNTRY \\
\hline Australia \\
Canada \\
Denmark \\
Japan \\
U.S.S.R. \\
United Kingdom \\
United States
\end{tabular}

Operating TV Stations

\begin{tabular}{rrr}
$\frac{1970}{82}$ & \multicolumn{2}{c}{1980} \\
76 & $118(\mathrm{~F})$ & $102(\mathrm{R})$ \\
1 & $409(\mathrm{~F})$ & $645(\mathrm{R})$ \\
$2200(\mathrm{~F} \& \mathrm{R})$ & $1102(\mathrm{~F})$ & $5333(\mathrm{R})$ \\
8 & $350(\mathrm{~F})$ & $1500(\mathrm{R})$ \\
96 & $281(\mathrm{~F})$ & $929(\mathrm{R})$ \\
872 & $1020(\mathrm{~F})$ & $3915(\mathrm{R})$
\end{tabular}

1971 Broadcasting Y.B. A-117, E-71-74; 1981 Broadcasting Cable Y.B. A-2, F-63-67; 50 TElevision FACTBOOK 341 -a (Services vol. 1981-82 ed.).

10. Space communications technology makes use of transmit stations (satellite "uplinks") on the ground, which relay programming or information to satellites orbiting in outer space. The satellites then retransmit the signal back to earth receive stations that may be connected by radio or wire to ultimate reception points. For a detailed discussion of satellite communications see Ploman, Salellite Broadcasting, National Sovereignty and the Free Flow of Information, in NATIONAL SOVEREIGNTY AND INTERNATIONAL COMMUNiCation 154 (K. Nordenstreng \& H. Schiller ed. 1979); Comment, International Regulation of Digital Satellite Systems, 32 FED. COM. L.J. 393, 410-36 (1980).

11. The geostationary orbit is the location approximately 22,300 miles above the earth's equator which permits a satellite placed there to remain in a stationary orbit with respect to the earth's rotation. 
which to position satellites. Adherence to precise technical standards will be necessary to optimize use of outer space for communications purposes. Moreover, because of the tremendous investment involved in deploying communications systems in outer space, the stakes in any controversy will be extremely high. ${ }^{12}$

In times of shortages of critical resources such as food and energy, effective communication networks can greatly facilitate the movement of resources to areas with the greatest need or, more realistically, to those with the deepest pockets. Equally important, free and open dialogue between nations can help to diffuse the increased tensions that can be expected to arise between the haves and the havenots. Although the technology exists to establish and maintain the necessary telecommunication networks for these purposes, it cannot be put to use in a climate of international conflict.

II

\section{ThE INTERNATIONAL TELECOMMUNICATION UNION}

The principal instrumentality for maintaining world order in telecommunication has been and continues to be the International Telecommunication Union (ITU), a specialized agency of the United Nations which headquarters in Geneva, Switzerland. ${ }^{13}$ The ITU's focus traditionally has been on the technical aspects of international telecommunication. Until recently, the organization generally has avoided becoming embroiled in political issues, concentrating instead on insuring that the airwaves remain free of interference and that the requisite degree of technical standardization exists for a free flow of information regardless of content. ${ }^{14}$ Events at the most recent ITU Plenipotentiary Conference in Nairobi, ${ }^{15}$ however, suggest that the ITU may face greater difficulties in the future in withstanding efforts of some member nations to use the organization as a forum for venting political and ideological concerns unrelated to telecommunication. As this article

12. Although the cost of satellite communication channels is dropping, it has been estimated that a direct broadcast satellite system consisting of three orbiting space satellites and a ground "back-up" can run as high as 400 million dollars. See SATELLITE WEEK, June 22, 1980, at 5.

13. The ITU was established in 1932 by the merger of the International Telegraph Union and the International Radiotelegraph Union. See International Telecommunication Convention, Dec. 9, 1932, 49 Stat. 2391, T.S. No. 867. A number of other international organizations also deal with telecommunication issues; however, they have more restricted memberships and deal with more limited aspects of telecommunication than does the ITU. For a discussion of some of the prominent ones see W. EMERY, NATIONAL and International Systems of Broadcasting: Their History, Operation and Control, 516-31 (1969); Note, Toward the Free Flow of Information: Direct Television Broadcasting via Satellite, 13 J. INT'L L. \& ECON. 329 (1979).

14. Provisions of the United Nations Charter and various international human rights agreements treat political and content-related telecommunication issues such as freedom of expression and propaganda. See Paust, Intemational Law and Control of the Media: Terror, Regression and the Aliematives, 53 IND. L.J. 621 (1978). Despite efforts to keep the ITU's focus technical, political issues have begun to surface at recent major ITU conferences. See, e.g., Dep't of State, RePORT OF THE ChaiRman OF THE UNITED States Delegation to the World administrative Radio Conierence of the International Telecommunication Union 106 (T.D. No. 116, 1979) [hereinafter cited as 1979 WARC Report]; Dep't of State, Report of the United States Delegation to the Plenipotentiar y Conference of the INTERNATIONAL TELECOMMUNICATION UNION 7-8 (T.D. No. 43, 1973) thereinafter cited as 1973 PLENIPOTENTIARY CONYERENCE REPORT].

15. See infra text accompanying notes 28-30. 
goes to press, the ITU has narrowly avoided an effort by Arab bloc nations to oust Israel from the Conference, an effort which prompted the United States, one of the ITU's major financial contributors, to threaten a walkout from the Conference and possible withdrawal from the organization. ${ }^{16}$ This unfortunate incident left no time for many critical telecommunication objectives on the conference agenda.

Pursuant to the International Telecommunication Convention, ${ }^{17}$ the ITU's governing document, the organization is authorized to promulgate regulations governing telecommunication practices of its members, to collect and disseminate information on telecommunication issues, to provide technical assistance to developing nations, and to engage in research and development on international applications of telecommunication technology. ${ }^{18}$ Inherent in the ITU's general objectives and specific duties is an important role in the prevention and resolution of international disputes. Full appreciation of this role requires a basic understanding of the ITU's background and current structure.

\section{A. Background}

The ITU is a direct descendant of the International Telegraph Union, which was established in 1865. ${ }^{19}$ ITU historian George A. Codding, Jr., contends that the present organization "can be considered the oldest existing international organization and the forerunner of many of the international organizations

16. See Communications Daily, Oct. 25, 1982, at 1.

17. International Telecommunication Convention, Oct. 25, 1973, 28 U.S.T. 2497, T.1.A.S. No. 8572 [hereinafter cited as 1973 Convention].

18. Article 4 sets forth the purposes and duties of the Union as follows:

1. The purposes of the Union are:

(a) to maintain and extend international cooperation for the improvement and rational use of telecommunications of all kinds;

(b) to promote the development of technical facilities and their most efficient operation with a view to improving the efficiency of telecommunications services, increasing their usefulness and making them, so far as possible, generally available to the public;

(c) to harmonize the actions of nations in the attainment of those ends.

2. To this end, the Union shall in particular:

(a) effect allocation of the radio frequency spectrum and registration of radio frequency assignments in order to avoid harmful interference between radio stations of different countries;

(b) coordinate efforts to eliminate harmful interference between radio stations of different countries and to improve the use made of the radio frequency spectrum;

(c) coordinate efforts with a view to harmonizing the development of telecommunications facilities, notably those using space techniques, with a view to full advantage being taken of their possibilities;

(d) foster collaboration among its Members with a view to the establishment of rates at levels as low as possible consistent with an efficient service and taking into account the necessity for maintaining independent financial administration of telecommunication on a sound basis;

(e) foster the creation, development and improvement of telecommunication equipment and networks in developing countries by every means at its disposal, especially its participation in the appropriate programmes of the United Nations;

(f) promote the adoption of measures for ensuring the safety of life through the cooperation of telecommunication services;

(g) undertake studies, make regulations, adopt resolutions, formulate recommendations and opinions, and collect and publish information concerning telecommunication matters.

Id. art. 4.

19. Convention Telegraphique Internationale de Paris, May 13, 17, 1865, Brit. \& For. St. Papers 56295. 
today."20 At the Berlin Radio Conference of 1906, a separate organization, the International Radiotelegraph Union, was formed to deal with the telegraph's wireless counterpart. ${ }^{21}$ The two organizations merged in 1932 to form the International Telecommunication Union. ${ }^{22}$

From 1932 to the present, the ITU has survived a World War and numerous international conflicts and has adapted to coordinate the ever-increasing international use of rapidly developing telecommunication technology. ${ }^{23}$ Most recently, the Union has attempted to find a proper role for itself as it has taken on many new members with different kinds of telecommunication concerns. The ITU's membership of 78 countries in 1947 increased to 155 in $1981 .^{24}$ More importantly, the majority of these new members and, now, a majority of the organization's entire membership are developing nations that have begun to question the ITU's customary method of assigning frequencies, ${ }^{25}$ to demand technical assistance for their incipient national telecommunication systems, and sometimes to inject a degree of north-south politics into ITU proceedings. ${ }^{26}$

\section{B. The ITU's Current Structure}

Over the years the ITU has evolved a structure of plenary and permanent administrative components recognized as being unique in the community of international organizations. A study of the ITU conducted before the most recent assembly of the organization's general membership (Plenipotentiary Conference) was somewhat critical of the ITU's structure:

Its organizational growth has mirrored the growth of international communication: as the latter has developed, new organs and functions have been grafted onto the pre-existing ITU structure, with relatively little throught as to how well the old and new parts fitted together.

The result is a plethora of different conferences, assemblies, organs, and secretariats. ${ }^{27}$

Despite these perceived deficiencies, the study ultimately concluded that the ITU's structure was fundamentally sound and in no need of major change.

20. G. Codding, JR., The International Telecommunication Union 4 (1952) [hereinafter cited as Codding (1952)].

21. International Wireless Telegraph Convention Nov. 3, 1906, 37 Stat. 1565, T.S. No. 568. See also CoDDing (1952), supra note 20, at 84-108.

22. See supra note 13.

23. See generally D. Leive, The Future of the International Telecommunication Union, a RePort for the 1973 Plenipotentiary Conference Panel on International TelecommunicaTION POLICY (1972) [hereinafter cited as 1973 Policy RePORT]; Mili, Plenipotentiary Conference, a Preliminary Assessment, The ITU Renewed, 41 Telecom. J. 2 (1974); Rutkowski, The 1979 World Administralive Radio Conference: The ITU in a Changing World, 13 INT'L LAW 289 (1979).

24. The $60 \%$ increase in the Union's membership since 1959 is entirely due to the addition of developing nations. See 1979 WARC REPORT, supra note 14, at 16.

25. The ITU traditionally has considered first use and registration important in establishing priorities among frequency assignments. Poorer countries and developing nations that have only recently entered the telecommunication field in a meaningful way tend to see this policy as unduly favoring more affluent or industrialized nations. As an alternative, the emerging nations advocate assignment of frequencies in advance of actual use, giving each country its fair share. See Rutkowski, supra note 23, at 293-94.

26. The scope of this article does not permit a detailed discussion of the issues that divide industrialized and developing member nations of the ITU. For an in-depth treatment of this topic, see 1979 WARC REPORT, supra note 14; Codding, The United States and the ITU in a Changing World, 44 TELECOM. J. 231 (1973) [hereinafter cited as Codding (1973)].

27. See 1973 POLICY REPORT, supra note 23, at 2. 
1. The Plenipotentiary Conference. The supreme authority of the ITU rests in its Plenipotentiary Conference, which consists of all member nations and convenes approximately once during every decade. ${ }^{28}$ Only the Plenipotentiary Conference can revise the International Telecommunication Convention. ${ }^{29}$ This body also fixes the organization's budget and fills key administrative positions by electing a thirty-six member Administrative Council from the ITU general membership and by appointing the organization's Secretary General. ${ }^{30}$

2. The Administrative Council. The Administrative Council meets for one month each year between Plenipotentiary Conference years. This body is responsible for implementing ITU policies and regulations and overseeing the administrative work of the Union's General Secretariat. In electing the Council, the Plenipotentiary Conference must attempt to insure the representation of all regions. ${ }^{31}$

3. The General Secretariat. The Secretary General is the chief executive and legal representative of the ITU. He is responsible for carrying out the orders of the Administrative Council and managing the ITU's permanent staff. ${ }^{32}$

4. The Administrative Conference. Regulations implementing the Convention and ITU policy are promulgated by World and Regional Administrative Conferences that meet at irregular intervals to consider special telecommunication matters such as radio frequency allocation and satellite communications. ${ }^{33}$

5. The International Frequency Registration Board. The important task of international frequency coordination is entrusted to the International Frequency Registration Board (IFRB), a permanent ITU organ whose five members are technical experts elected by the Plenipotentiary Conference. ${ }^{34}$

6. The Consultative Committees. The research and development activities of the ITU are the principal responsibility of the International Radio Consultative Committee and the International Telegraph and Telephone Consultative Committee. ${ }^{35}$ These permanent bodies and their subsidiary study groups conduct on-going research and make recommendations on specific technical questions. ${ }^{36}$

\section{III}

\section{The ITU'S Role in The Management of InTERnational Telecommunication Conflicts}

Although the ITU is empowered to play a role in both the prevention and the

28. 1973 Convention, supro note 17 , arts. 6, 53.

29. Id. art. 6(2)(i).

30. Id. art. $6(2)(f),(\mathrm{g})$.

31. Id. arts. 7,55 .

32. Id. arts. 9,56 .

33. Id. arts. $7,54$.

34. Id. arts. 10,57

35. Id. arts. 11,58 ,

36. The work of the Consultative Committees in promulgating recommendations recently has taken on greater significance. Because the Consultative Committees and their study groups are smaller than the Administrative Conferences and because they function on an on-going basis, they can deal with rapidly changing technology more effectively and quickly. Although the recommendations do not have the same legal status as do the regulations, the strength of both kinds of official statements depends upon voluntary compliance of ITU members. Accordingly, the practical advantages of recommendations are seen as outweighing their inferior legal status. See Mili, supro note 2, at 562-66. 
resolution of international telecommunication conflicts, greater emphasis is placed on its preventative role. This focus reflects the reluctance of the organization's members, all sovereign states, to relinquish much control over the attainment of their national telecommunication objectives. ${ }^{37}$ Thus, the ITU operates principally as a forum in which the nations of the world attempt to achieve consensus on general standards of telecommunication conduct that are more or less acceptable, if not to the entire membership, then at least to the majority. ${ }^{38}$

\section{A. Conflict Prevention}

Quite a few of the ITU's activities are informative and educational. The research of the Consultative Committees, the technical assistance programs, and the ITU's publications all contribute to the prevention of conflict between nations by making them aware of situations in which clashes are likely to occur and of the means for averting them. ${ }^{39}$ Nations well informed on telecommunication matters are less likely to blunder into conflicts inadvertently. If a nation is inclined to cooperate, ITU educational efforts will better equip it to do so.

The ITU also serves "as a forum at which agreements [are] reached as to what part of the radio spectrum would be used for what purpose by what countries in what part of the world." 40 More recently, the organization has also commenced efforts to coordinate placement of communications satellites in the geostationary orbit. ${ }^{41}$ These duties, principally the responsibility of the IFRB, are the most important component of ITU's ability to prevent international conflicts.

By maintaining a record of frequency assignments and usage as well as of details on space communications systems, the IFRB enables ITU members to avoid coming into conflict with each other. ${ }^{42}$ In deploying satellite communication systems or initiating use of certain frequencies in international or domestic communication with international ramifications, ITU member administrators must notify the IFRB. The IFRB then (i) reviews each proposal for conformity with the Convention, regulations, and any applicable regional service agreement; (ii) examines it for potential interference with other assignments in the international register; and (iii) includes it in a weekly bulletin circulated among the other

37. See infro note 76 .

38. 1973 Convention, supra note 17 , art. 77(15).

39. In addition to its regular service publications (weekly circular letters; directories of addresses of member nations' telecommunication administrations, private operating agencies and scientific or industrial organizations; statistical yearbooks; and reports on various administratave conferences), the ITU publishes a monthly journal and a number of glossaries of technical terms and instructional manuals and handbooks dealing with topics such as telephone signalling and switching, joining of plastic-sheathed cables, protection of telecommunication equipment against lightning discharges and ionospheric propagation. Most of these publications are available in a trilingual edition (French, English and Spanish). The Union also sponsors training seminars held in various locations, with a particular emphasis on making the sessions easily accessible for developing nations. See International Telecommunication Union, List Or PubLICATIONS (Dec. 1980).

40. Ende, Intemational Communications: History of Intemational Radio, Cable and Satellite Communications; The Differences in Regulatory Approach from Domestic Communications; Special Intemational Relationships, Institutions, Law and Treaties, 28 FED. COM. B.J. 147, 163 (1975).

41. 1973 Convention, supra note 17, art. 4(2)(e); ITU Radio Regulations, art. 11 (1982).

42. The duties of the IFR B are set forth in ITU Radio Regulations, art. 10 (1982). 
members for comment or objection. ${ }^{43}$ Notices that pass Board review and draw no objection from other members are logged in the ITU record system as entitled to international recognition and protection against subsequent interfering uses. ${ }^{44}$ Proposed assignments that are inconsistent with the international allocation scheme or existing usage are appropriately noted in IFRB records and may give rise to additional Board activities discussed below. By consulting IFRB records and observing its coordination procedures, ITU members can avoid many conflicts. ${ }^{45}$

\section{B. Conflict Resolution}

In case ITU conflict prevention measures are unsuccessful, the Convention also provides procedures for resolving disputes after they arise. ${ }^{46}$ Although the IFRB's functions are mainly preventative, the Board is also empowered to assist member countries in resolving cases of interference resulting from actual or proposed use of frequencies or orbital slots. Because the IFRB's current role in conflict resolution is only a limited, advisory one, the integrity of the ITU's frequency allocation scheme must rely upon voluntary compliance. For the most part, the ITU strongly encourages members to find ways of resolving their disputes without involving the organization or its staff. Nevertheless, the Convention does provide for arbitration if the parties cannot agree on another method. ${ }^{47}$ Because the ITU procedures for conflict resolution combine the features of several well-accepted methods for resolving international disputes, it is helpful to consider the ITU procedures in the context of the general law of international conflict resolution.

1. International Conflict Resolution-Generally. It is well accepted that, absent force, no sovereign nation can be made to take any action, adhere to any code of conduct, or comply with any decision without its consent. ${ }^{48}$ Thus, the effectiveness of every peaceful method of conflict resolution is limited to some degree by the doctrine of state sovereignty. ${ }^{49}$ Although various legally recognized methods of conflict resolution frequently are referred to as binding or nonbinding, in reality they differ only with respect to when a nation's consent is given. Even in binding forms of conflict resolution such as arbitration and adjudication, the parties must consent

43. IFRB administered coordination, notification, and registration procedures, which vary for different radio services and frequency bands, are set forth in ITU Radio Regulations, arts. 11-17 (1982).

44. See, e.g., ITU Radio Regulations, art. 12, §13(2) (1982).

45. Pursuant to the 1973 Convention, art. 35, each ITU member nation is responsible for insuring that communications under its jurisdiction comply with international standards. In the United States, this responsibility rests with the FCC. The Communications Act of 1934, as amended, from which the FCC derives its regulatory jurisdiction, gives the agency authority over foreign commerce in wire and radio communication and empowers it, among other duties, to suspend the license of any operator who has violated the provisions of any treaty or convention to which the United States is a party. 47 U.S.C. $\$ \S 101$, 303(m) (1976).

46. See 1973 Convention, supra note 17 , art. 50.

47. Id. art. 81 .

48. See generally L. OpPENHEIM, INTER National LAw 117-23 (H. Lauterpacht 8th ed. 1955).

49. See generally W. Reisman, Nullity and Revision: Review and ENFORCEMENT OF INTER.N.ATIONAL JUDGMENTS AND AWARDS (1971). 
to submit their dispute to the tribunal in question. Implicit in submission of the matter is the agreement to be bound by the tribunal's decision. ${ }^{\mathbf{5 0}}$

Nonbinding forms of conflict resolution typically are used when nations wish to retain maximum control over the conduct and outcome of the proceedings. Disputing nations may undertake to resolve a conflict strictly on their own through diplomatic channels or with minimal involvement of a third party as in good offices, mediation, or conciliation. In either case, the parties to the dispute do not agree in advance on exactly what will take place, nor do they agree to await a third-party decision and to be bound by it. The consent of the parties must be present at all times in order for the process to go forward.

Although nonbinding forms of conflict resolution are flexible, they lack both certainty and objectivity. In diplomatic conflict resolution, both parties are represented by advocates who may find it difficult to view the issues in dispute impartially. Moreover, the same diplomatic personnel charged with resolving a conflict in one situation may be waging a conflict in another. ${ }^{51}$ Because their responsibilities are numerous and varied, ambassadorial personnel may be hampered in their ability to resolve a conflict by a lack of specific knowledge or of the opportunity to devote their full attention to the subject matter at hand. Use of good offices, conciliation or mediation may inject greater objectivity into the process, but these methods also lack certainty. Furthermore, the neutral third party neither finds facts nor renders decisions, but merely facilitates communication between the parties and makes informal, nonbinding suggestions if asked. As in diplomatic conflict resolution, the success of good offices, conciliation and mediation finally depends on the agreement of the parties.

It is well recognized that nations are somewhat reluctant to submit disputes to forms of resolution considered to be binding, particularly adjudication. Thus, as Reisman points out, "When state elites have submitted matters to adjudication, the subject of the dispute has often been of minor consequence."52 Nevertheless, adjudication is not without its advantages. Resort to an international judicial body eliminates the time-consuming and difficult task of constituting a tribunal after the dispute has arisen and affords greater certainty through prescribed procedures and decisions based on precedent. Whether because of the commitment a nation makes in submitting a matter to adjudication, the prestige of the tribunal, the nation's desire to avoid adverse international reaction, or simply the inconsequential nature of the matter submitted, compliance with international adjudicatory orders has been found to surpass that of other forms of international conflict resolution. ${ }^{53}$

Arbitration is somewhat less predictable than adjudication, principally because the arbitral tribunal is usually constituted specifically for each case and reaches its

50. See J. Simpson \& H. Fox, International Arbitration: Law and Practice 42 (1959). The parties may consent to submit their dispute for settlement after it has arisen or far in advance as, for example, when they sign a treaty or join an international organization that provides for resolution of conflicts exclusively by arbitration or adjudication.

51. See P. Jacob, A. Atherton \& A. Wallenstein, The Dynamics of International OrganiZation: The Making or WORld ORDER 258 (rev. ed. 1972).

52. W. REISMAN, supra note $49,222-23$.

53. Id. at 226-27. 
decision on the basis of equity rather than legal precedent. ${ }^{54}$ These features are sometimes viewed as advantages, however, because they allow the parties greater input on how a conflict will be resolved. Thus, arbitration combines some of the flexibility of nonbinding forms of conflict resolution with the basic commitment to await an end result that exists in adjudication. Among the accepted forms of arbitration are the single arbitrator, who is selected by agreement of the disputants; the joint commission that consists of two arbitrators, one representing each side or party; the mixed commission (basically a joint commission with recourse to a neutral umpire in the event of a deadlock); and the collegiate court composed of a member appointed by each side and an uneven number of neutral members selected jointly by the first two members, by the agreement of the parties or by some disinterested party. ${ }^{55}$ Speed and administrative efficiency are often sacrificed in an effort to constitute a more impartial arbitral tribunal.

2. ITU Conflict Resolution Procedures. The ITU is not designed to serve as a forum for conflict resolution. ${ }^{56}$ Because of the reluctance of its members to submit their disputes in every instance to binding resolution, the absence of a permanent arbitral tribunal or judicial body within the ITU is no accident. Nevertheless, in recognition of the fact that disputes are bound to arise and that an international organization may provide a convenient forum for resolving them, the Union's members have agreed to certain measures for dealing with conflicts after they arise.

a. The IFRB's Role. Should the Board discover a case of potential or actual interference ${ }^{57}$ through its own review of a notice or through the objection of an ITU member, it advises all interested nations and can assist them in resolving the problem. Even though the ITU's international frequency coordination scheme is intended principally to prevent conflicts, the IFRB's duties include the rendering of special assistance, "the investigation, at the request of one or more of the interested administrations, of harmful interference, and the formulation of recommendations with respect thereto." 58 In responding to requests for special assistance, the IFRB's activities have some of the features of mediation. If both parties or sides in a frequency conflict are willing, the Board can facilitate communication between them and can make recommendations as to how the problem can be solved. Moreover, Board members must act not as representatives of their respective countries but as "custodians of an international public trust." 59 As a result, conflict resolution by the IFRB is likely to have more objectivity than would normally exist in mediation in which the parties select the mediators. The IFRB's role in conflict resolution is somewhat broader than the usual role of mediator in that the Board is engaged in

54. See J. Brierly, The LaW of Nations 256 (4th ed. 1949).

55. Some forms of arbitration are discussed in greater detail in J. SimPSON \& H. FoX, supra note 50 , at 34-39.

56. See infra note 76 and supra note 38 .

57. In certain circumstances, IFRB procedures allow for the giving of notice after a frequency has been put into use. ITU Radio Regulations, art. 12, §3(1) (1982). In addition, ITU members are encouraged to report cases of infringement of the Convention or noncompliance with the regulations. 1973 Convention, supra note 17, art. 24; ITU Radio Regulations, arts. 21, 22 (1982).

58. ITU Radio Regulations, art. 11, § 2(g) (1982) (emphasis added).

59. 1973 Convention, supra note 17 , arts. $10(2), 59(4)$. 
fact-finding. Given the requirement that Board members possess special technical qualifications, ${ }^{60}$ however, their investigative powers seem justified. Although the IFRB is empowered to investigate and advise, it lacks positive enforcement authority and cannot impose any particular solution or, indeed, any solution at all on the parties in conflict. ${ }^{61}$

b. ITU Arbitration. If conflicts are not resolvable through IFRB special assistance procedures, the Convention encourages members to settle their disputes involving interpretation or application of the Convention or Regulations outside the ITU through diplomatic channels, procedures established by other treaties to which they are parties, or "any other method agreed upon."62 Only in the event that the parties to a dispute find these alternatives unacceptable does the Convention provide for direct involvement of the ITU, and then in only the most limited way.

If the parties cannot agree on another method, the Convention provides that conflicts between ITU members may be resolved by arbitration. ${ }^{63}$ Even within the context of the arbitration provision, the parties have a great deal of latitude. They may select either a single arbitrator or a collegiate court composed of two members - one appointed by each party or side-who jointly select a third, neutral member. ${ }^{64}$ If the disputing parties cannot agree on a single arbitrator, the Convention provides that each must nominate a candidate between whom the ITU Secretary General will select by drawing lots. ${ }^{65}$ The same procedure is followed if the first two members of a collegiate court cannot agree on the third. ${ }^{66}$

The arbitration provision also contains procedures to insure that conflicts are resolved as quickly and as fairly as possible. In an effort to avoid unnecessary delays associated with constituting a tribunal, there is a time limit of three months for appointment of arbitrators. ${ }^{67}$ A provision requiring the parties to share equally in the cost of arbitration reduces uncertainty in this area. ${ }^{68}$ Where the members of the tribunal will be individuals, none can be a citizen, domiciliary or employee of any party to the dispute. ${ }^{69}$ Similar restrictions are placed on governments or administrations that serve as tribunal members. ${ }^{70}$

A number of the ITU member countries have gone one step beyond the Convention's arbitration provision by accepting compulsory arbitration for the settlement of disputes in which they are involved. Pursuant to an Optional Additional Protocol, these countries have agreed that if none of the other methods of resolution provided for in article 50 are agreed upon by common consent, "disputes

60. Id. art. 57(1), (2).

61. ITU Radio Regulations, art. 10, § 2(g) (1982).

62. 1973 Convention, supra note 17 , art. $50(1)$.

63. Id. art. 50(2).

64. Members of the tribunal may be individuals, governments or national telecommunication administrations. Id. art. 81(2).

65. Jd. art. $81(7)$

66. Id. art. $81(8)$.

67. Id. art. 81(5).

68. Id. art. $81(11)$

69. Id. art. 81(3).

70. Id. art. 81(4). 
concerning the interpretation or application of the Regulations . . shall, at the request of one of the parties to the dispute, be submitted to arbitration."71 In contrast, the 1973 Convention itself provides that if another method of resolution is not selected, disputes may be settled by arbitration in accordance with the arbitration procedures. ${ }^{72}$

\section{IV}

\section{An Assessment}

The ITU's role in the management of telecommunication conflicts definitely is geared toward prevention, and only limited, noncontroversial participation is envisioned in conflict resolution. By conferring certain powers on the IFRB and by establishing an arbitration procedure, the Plenipotentiary Conference has created an opportunity for the settlement of disputes that cannot be prevented. Nevertheless, there is an apparent reluctance among ITU members officially to involve organization machinery in the conflict resolution process.

Although the IFRB's expertise and investigative powers enable it to do more than a traditional mediator, it lacks the authority of an arbitrator or adjudicator to render binding decisions. Apart from the Board and its limited role in interference matters, the only ITU organ with an official role in conflict resolution is the Secretary General, whose function of drawing lots to break deadlocks in the selection of arbitrators is neither substantive nor otherwise significant. ${ }^{73}$ It is possible that in devising their own method for settling a dispute under article 50 of the 1973 Convention the parties could agree to involve an ITU functionary as mediator or arbitrator. Although the Convention does not appear to preclude this, neither does it encourage such use of its personnel. Finally, when the citizens, government, or telecommunication administrations of ITU member countries serve on arbitral panels under article 81 , they are intended to do so in their own capacities and not as official agents of the ITU.

From time to time it has been suggested that the ITU needs to become more active in the conflict resolution process, ostensibly because the higher stakes involved in contemporary telecommunication conflicts warrant it. ${ }^{74}$ Among the alternatives proposed are the creation within ITU of a World Communications Court or the enlargement of the IFRB's functions to include settlement of disputes by arbitration. As telecommunication continues its rapid development, and as more and more countries take advantage of the new technologies, it is appropriate to reassess the organization's role in conflict management to determine whether a new and stronger approach toward conflict resolution really is necessary.

71. Optional Additional Protocol to the International Telecommunication Convention, Oct. 25, 1973, Compulsory Settlement of Disputes, 1975 Austl. T.S. 24, art. 1 (emphasis added). It is noted that most major powers, including the United States, have neither signed nor acceded to this protocol.

72. 1973 Convention, supra note 17, art 50(2) (emphasis added).

73. Id., art. $81(7),(8)$.

74. See, e.g., D. Leive, International Telecommunications and International Law: The Regulation of the Radio Spectrum 313-15 (1970); John and Mary R. Markle Foundation, Global Communications in the Space Age: Toward a New ITU 15-17 (1973) [hereinafter cited as MARKLE REPORT]. 
One way to evaluate the need for such change is to examine the history of conflict resolution in the ITU, with particular emphasis on arbitration, currently the strongest available measure for settlement of disputes between ITU members. In the past, the arbitration procedures have been largely ignored, with members preferring to resolve their disputes through bilateral negotiation. ${ }^{75} \mathrm{~A}$ further indication that expansion of ITU jurisdiction might not be very effective is the fact that only about one-third of the ITU's members, and few major powers, have agreed to submit their disputes to binding arbitration by signing the Additional Optional Protocol on settlement of disputes. ${ }^{76}$ Most important, the reluctance of nations to resort to binding forms of conflict resolution administered by an ITU organ in the past does not appear either to have diminished the organization's effectiveness or to have adversely affected world telecommunication order. If experience in other areas of international endeavor is any indication, the higher the stakes in telecommunication disputes become, the less likely nations will be to submit to binding third-party resolution. ${ }^{77}$

Even if more nations agree to strengthen and expand the ITU's role in conflict resolution, there is no guarantee that conflicts will be resolved more rapidly or effectively. It is well recognized that binding forms of conflict resolution can be substantially weakened by qualifying their applicability. ${ }^{78}$ Moreover, parties to an adjudication or arbitration can legitimately employ devices such as requests for interpretations, appeals or even withdrawal from ITU to delay or avoid complying with binding decisions that are unfavorable. ${ }^{79}$

General experience in international affairs suggests that conflicts are most likely to be resolved when nations are given a choice of the method they will use to settle their differences. ${ }^{80}$ In resolving telecommmunication disputes, ITU members can select among all the established forms of international conflict resolution and can even devise new methods of their own. By not excluding any method of conflict resolution, the ITU Convention makes available the benefits of them all:

75. As Leive notes, precise statistics are not kept on resolution of ITU member disputes by arbitration or other means. See D. LEIVE, supra note 74, at 129-36. Of the few cases in which resort to arbitration was attempted, none involved harmful interference. The one significant reported arbitration case under ITU procedures involved a 1935 dispute over suspension of telegraph services. See Affaire de la Société RadioOrient (Fr. v. Egypt), 3 R. Int'l Arb. Awards 1871 (1980), 37 AM. J. INT'L L. 341 (1943). See also CoDding (1952), supra note 20, at 309-11; MARKLE REPORT, supra note 74, at 16.

76. Conspicuously absent from the signatories to this Protocol are Great Britain, the United States, the Soviet Union (and other Soviet bloc states), France, and West Germany, all major industrialized users of telecommunications. It has been suggested that more powerful nations are content to entrust their welfare in international conflicts to the wielding of their considerable political or economic clout, while less powerful countries desire the intervention of a major international organization on their behalf. See, e.g., D. LEIVE, supra note 74, at 27.

77. See supra note 52 and accompanying text.

78. See, e.g., Bernhardt, Compulsory Dispute Settlement in the Law of the Sea Negotiations: A Reassessment, 19 VA. J. INT'L L. 69, 73-98 (1978).

79. Article 47 of the 1973 Convention contains procedures for denunciation of the Convention by member states. For further legal discussion of this topic, see generally W. REISMAN, supra note 49 , at 637 73; Akehurst, Withdrawal from International Organizations, 32 CurRent Legal Probs. 143 (1979).

80. For a discussion of the relative degree of success that other international organizations have achieved in resolving disputes, see Bockstiegel, Arbitration and Adjudication Regarding Activities in Outer Space, 6 J. SPACE L. 3, 18 (1978). 
the control of bilateral negotiations, the flexibility of mediation, the objectivity of arbitrations, or the certainty of adjudication.

In the final analysis, the success of any international endeavor requires the voluntary cooperation of the sovereign nations involved. Realistically, such cooperation is most likely to exist when it is in a nation's self-interest. One survey of international organizations recognized, "In some cases, the very nature of the functions of the agency gives it a more effective sanction (i.e., where the agency can withhold a valuable service from members)."81 Catering to its members' selfinterests is one of the ITU's greatest strengths. If, for example, a member nation desires international recognition and protection of its frequency assignments, it must adhere to international standards. When a frequency conflict arises despite preventative measures, it is often in the parties' interests to follow the IFRB's advice, if not as a means of eliminating an immediate case of interference then as a way of insuring cooperation of other nations in future situations.

As nations become more reliant on telecommunication, they will be less able to ignore situations that render their services unusable. Similarly, as their level of financial commitment to telecommunication facilities and services increases, nations will be less willing to risk actions that would diminish the return on investment. In satellite communication, the great cost and difficulty of eliminating harmful interference after it has occurred makes educational and informational activities more important. Clearly, the incentives for international cooperation before conflicts arise can only be expected to become stronger.

Recent events suggest that the ITU's first priority should be to fight for its life by discouraging political and ideological confrontation unrelated to telecommunication. Assuming that the organization can continue not only to survive but also to function effectively in the current international climate, it must continue to work for consensus among nations in establishing acceptable but effective standards for preventing telecommunication conflicts. Given the inherent limitations on all conflict resolution mechanisms, the ITU's resources are best used to educate its members and thereby to enhance their ability and willingness to comply with international standards. It is doubtful that engrafting new judicial organs on the present ITU structure, increasing the authority of the IFRB, or involving other ITU organs more extensively in conflict resolution will be more effective than the present basic approach.

This is not to say, however, that the existing procedures cannot be improved. If the present emphasis and reliance upon conflict prevention is to continue, the Union must make it easier for ITU members to understand the standards that apply. The present regulations fill several volumes, and like many domestic government regulatory schemes they suffer from ambiguity and unnecessary use of "bureaucratese." 82 The need for precision and clarity is especially acute when regulations deal with highly technical matters.

81. D. BowetT, The LaW OF INTERnational Institutions 128 (1963). See also D. Leive, supra note 74 , at $24-25$.

82. "Bureaucratese" is a confusing and verbose language frequently employed by government officials and understood only with great difficulty by members of the public for whose benefit it is used. 
In addition, the importance of the Union's technical assistance programs and other educational efforts should not be underestimated. In the past, the United States and other technically advanced ITU member nations have been somewhat reluctant to support these efforts. ${ }^{83}$ As major financial contributors to ITU, these nations are understandably concerned that the organization's funds are spent wisely. ${ }^{84}$ Nevertheless, if proper controls are employed, it is in all ITU members' best interests that less technically sophisticated countries acquire the necessary knowledge and skill to operate their national telecommunication facilities in accordance with accepted international standards.

Finally, the cost of equipping the IFRB to serve as an arbitrator or adjudicator of disputes is not warranted either by the number of times members are likely to resort to such a tribunal or by the likelihood of compliance with its decisions. Nevertheless, the IFRB can be made more effective in the mediation and conciliation of conflicts if care is taken to appoint well-qualified, technical experts to serve as Board members and to provide them with the resources they need to carry out their mission. ${ }^{85}$ Even though it is essential to keep political considerations from dominating the conflict resolution process, the Board members and staff must be aware of the political and social ramifications of their technical findings. In addition, the Board should not be required to wait until requested by the parties to become involved in a conflict, but should be empowered to attempt to initiate discussions or offer suggestions.

Above all, reformers of the ITU should always bear in mind, particularly before substantial financial commitments are made, that the Union has been and will continue to be most effective when it capitalizes upon the self-interests of member countries. The ITU's efforts in informing and educating its members will be especially important in identifying those self-interests.

83. See, e.g., Codding (1973), supra note 26 , at 231.

84. Article 15 of the Convention, which governs the Union's finances, allows for members to elect the size of contribution they will make. See 1973 Convention, supra note 17, art. 15.

85. The importance of well-qualified civil servants to the effectiveness of any international organization is discussed generally in James, The Concept of the International Civil Service, in INTER NATIONAL ADMINIStRATION: Its EVOlution AND CONTEMPORARy APPlications (R. Jordan ed. 1971). 